\title{
Genetic Selection Barriers in Global Development of Rural Goat Production and a Simplified Approach in Identification of Proper Polymorphic Types
}

\section{E.K. Barbour ${ }^{1 *}$, M.F. Saade ${ }^{1}$, S.K. Hamadeh ${ }^{1}$, H.A. Shaib ${ }^{1}$}

\section{2,A. Abdelnour ${ }^{3}$, S. Harakeh ${ }^{4}$ and Taha Kumosani ${ }^{5}$}

${ }^{1}$ Department of Animal and Veterinary Sciences (FAFS), American University of Beirut, Beirut, Lebanon and Adjunct Professor at King Abdulaziz University, Jeddah, Saudi Arabia ${ }^{2}$ Nutrition and Food Sciences, FAFS, AUB, Lebanon

3 Institute of Polytechnique LaSalle Beauvais, 19 rue Pierre Waguet, 60000 Beauvais, France

${ }^{4}$ King Fahad Medical Research Center, King Abdulaziz University, Jeddah 21589, Saudi Arabia

${ }^{5}$ Biochemistry Department, Faculty of Science and Experimental Biochemistry Unit, King Fahad Medical Research Center, King Abdulaziz University, Jeddah, Saudi Arabia

\begin{abstract}
The lack of enough funding for rural development projects is hindering the genetic characterization of goats around the globe. This is the first simplified recognition of multiple polymorphism of production, immunity, and health genes of sperms in rural goats, paving in its potential towards adoption of this model for future selection programs, targeting a direct improvement of rural goat herds, and aiming at an indirect benefit to the poor shepherd's livelihood around the globe. The multiple polymorphism was studied in the sperms' production genes (Growth Hormone, and aS1-Casein), immunity gene (MHC Class II DRB), and Transmissible Spongiform Encephalopathy (TSE) resistant gene (PrP). The known genome of Saanen goat sperms was used as a control-reference in this research. There was a difference in the frequency of polymorphic types in PCR-amplicons of Growth Hormone subjected to HaellI restriction endonuclease, of aS1-Casein subjected to Xmnl enzyme, MHC class II DRB subjected to $\mathrm{Taql}$ endonuclease, and PrP subjected to amino acid sequencing. The recognition of multiple polymorphisms in important production, immunity, and health related sperm genes of rural goats, could be used in a reliable model for establishing future selection programs aiming at improvement of food security and safety in rural areas.
\end{abstract}

Keywords: Rural Goats; Sperm; Genes; Multiple Polymorphism; Production; Immunity; Health

\section{Introduction}

The World Bank estimated the rural fertile area of our planet is $38 \%$ [1]. The number of families living in rural areas of the world and involved in goat production is around 111 millions, with a total number of served rural goats equivalent to 833 million heads [2,3]. Most of the goat shepherds and their families are living below the poverty line [4,5], which is blamed mostly on the low productivity, poor veterinary services, and disease susceptibilities of their goats [6-8]. The genetic potential of most rural goats present on our planet is not yet characterized due to lack of funding, which is becoming more critical during the economic crisis of our time [9].

This lack of genetic characterization in rural goats prevents the breeders from implementing genetically-based selection programs for improvement of their productivity, immunity, and health $[10,11]$. The genetic-based selections are replacing the old phenotypic-based programs in the developed countries, due to the better advantages in accurate prediction of improvements in production, immunity, and health of the offsprings expected to be produced from the selected animals [12]. In France, the characterized genetic make-up of Saanen goats [13] led to implementation of successful selection program model that resulted in highly productive and proliferative goats [14]. The average milk production in rural Shami goats per year is 250 to $500 \mathrm{~kg} /$ doe [15], while the genetic-based selection model applied in Cyprus on Shami goats led to a yearly range in milk yield per doe of 350 to $650 \mathrm{~kg}$ [16]. Other developed countries were able to implement geneticallybased selection program for improvement of the meat production in goats [17]. Unfortunately, most of the above mentioned genetic-based selections focused on production genes and neglected the immunity, and disease resistance genes [13-16].
The importance of the use of polymorphic type-model for GH and aS1-Casein genes in selection for improvement of production traits is documented in literature $[18,19]$. The sporadic use of immunitypolymorphic markers in MHC-Class II DRB and the resistant-PrP genes were instrumental in breeding, targeting respective improvement of immunity [20], and the selection for resistance to Transmissible Spongiform Encephalopathy (TSE) [21,22]. It is worth noting that no previous work did look at combined multiple polymorphism (production, immunity and resistance to $\mathrm{PrP}^{\mathrm{sc}}$ ) in rural goats' sperms, to form a baseline data for future inclusive selection programs.

The objective of this research is to report for the first time a preliminary recognition of polymorphism in a wide spectrum of sperm genes, targeting future improvement of production, immunity, and resistance to Transmissible Spongiform Encephalopathy (TSE) in rural goats.

\section{Materials and Methods}

\section{Goats and Sperm Collection}

The reference Saanen goat sperms, collected from a mature male,

*Corresponding author: Elie K. Barbour, Department of Animal and Veterinary Sciences (FAFS), American University of Beirut, Beirut, Lebanon, Tel: +961-1350000, Ext:4460; Fax: +961-1-744460; E-mail: eb01@aub.edu.lb

Received December 20, 2012; Accepted January 05, 2013; Published January 07, 2013

Citation: Barbour EK, Saade MF, Hamadeh SK, Shaib HA, Kassaifi Z, et al. (2013) Genetic Selection Barriers in Global Development of Rural Goat Production and a Simplified Approach in Identification of Proper Polymorphic Types. J Veterinar Sci Technol S11: 004. doi:10.4172/2157-7579.S11-004

Copyright: (c) 2013 Barbour EK, et al. This is an open-access article distributed under the terms of the Creative Commons Attribution License, which permits unrestricted use, distribution, and reproduction in any medium, provided the original author and source are credited. 
Citation: Barbour EK, Saade MF, Hamadeh SK, Shaib HA, Kassaifi Z, et al. (2013) Genetic Selection Barriers in Global Development of Rural Goat Production and a Simplified Approach in Identification of Proper Polymorphic Types. J Veterinar Sci Technol S11: 004. doi:10.4172/21577579.S11-004

Page 2 of 7

imported from France, were used in all optimization procedures of the Polymerase Chain Reaction (PCR), targeting the amplification of four inclusive genes namely, the two production genes of GH and $\alpha \mathrm{S} 1$ Casein, the immunity gene of MHC Class II DRB, and the PrP gene for TSE susceptibility recognition [23,24]. Four major service rural male goats were selected for semen collection due to their wide-spread use in insemination of four largest herds reared in the rural areas at the Eastern side of the Mediterranean Sea, located at Latitude of $33^{\circ} 00^{\prime} \mathrm{N}$ and Longitude of $35^{\circ} 50^{\prime} \mathrm{E}$.

The semen samples were collected from the reference Saanen goat and from the rural goats in sterile urinary cups, using an electroejaculator (Standard Precision Electronics, Inc. Denver, Colorado). The samples were shipped on ice to the Animal and Veterinary Science Laboratories of the American University of Beirut, and stored at $-20^{\circ} \mathrm{C}$ for genetic analysis.

\section{DNA Extraction from Goat's Sperms}

The QIAamp DNA Mini Kits were used for DNA extraction from the goat's sperms, following the protocol of the manufacturer (Qiagen 2007 edition, Qiagen GmbH, D-40724, Hilden). Briefly, the enzyme Proteinase K was used for lyses of the sperms, and the QIAamp Mini spin columns were used for elution of the extracted DNA. The extracted DNA from the Saanen and the rural goats were stored at $-40^{\circ} \mathrm{C}$. The stored Saanen DNA was used to optimize the PCR for amplification of the four targeted genes, as described in our previous publications $[23,24]$, and the stored rural goat DNA were subjected to the optimized PCR protocols, to produce amplicons for further polymorphism analysis.

\section{PCR Optimization}

The PCR optimization of the four genes was performed on reference Saanen sperms, as described previously in details $[23,24]$. Briefly, the optimization used a constant sperm-DNA concentration of $93.0 \mathrm{ng} / 50$ $\mu \mathrm{l}$ in the PCR mixture. The variables used in the optimization were the primers concentration, thermal and cyclic conditions applied to the PCR reactions. The optimized protocols for the PCR of each of the multiple genes in the Saanen sperms are presented in Table 1. The same optimized protocols were applied on rural goat sperms to amplify the same four genes, enabling the study of their multiple polymorphisms.

\section{Polymorphism in Rural Goat Genes}

To detect polymorphism in rural goat genes, restriction endonuclease procedures were applied on the DNA amplicons of $\mathrm{GH}$, aS1-Casein, and MHC Class II DRB genes, while a nucleotide sequencing procedure was applied on the amplicons of the $\operatorname{PrP}$ gene. The Saanen DNA was included in every analysis as a reference. Briefly, the restriction endonuclease procedures were applied on the amplicons of GH, aS1-Casein, and MHC Class II DRB using the following respective enzymes (20 units/PCR mix) namely, the HaeIII, XmnI, and TaqI or PstI (Fermentas International Inc., 830 Harrington Court, Burlington, Ontario, C7N3N4, Canada). The incubation temperature and time of the enzymatic reaction were $37^{\circ} \mathrm{C}$ and 16 hours, respectively. The digested amplicons were banded on 2\% agarose, visualized and documented by UV, using GelDoc system (Bio-Rad Laboratories, 1000 Alfred Nobel Prize, Hercules, CA, USA). The nucleotide sequencing was performed on the amplicons of the PrP gene. Briefly, the G2reverse primer (Table 1) was included at $5 \mathrm{pmol} / \mu \mathrm{l}$, and the Dynamic ET (GE Health Care, 81050, USA) was added in $2 \mu \mathrm{l}$ volume to $\operatorname{PrP}$ amplicon that is eluted from the Agarose Gel. The rest of the sequencing steps followed the instructions for sequencing by the ABI-Prism 3130 , Applied Biosystems, UK. The coded amino acids from the determined PrP sequence were deduced by using the Basic Local Alignment Search Tool (BLAST) of the National Center for Biotechnology Information (Bethesda, MD 20894, USA).

\section{Results}

\section{Polymorphism in growth hormone $(\mathrm{GH})$ gene}

The polymorphism in GH gene of rural goats sperms is deduced from the electrophoretic patterns of DNA fragments resulting from the HaeIII endonuclease digestion of amplified exons 2 and 3 (Figure 1) and exon 4 (Figure 2).

The digestion of exons 2 and 3 by the HaeIII endonuclease enzyme resulted in three different sizes of DNA fragments namely, the $435 \mathrm{bp}$, $415 \mathrm{bp}$, and the $206 \mathrm{bp}$ (Figure 1). However, the digestion of the exon $4 \mathrm{GH}$ gene resulted in two different sizes of DNA fragments namely, the $115 \mathrm{bp}$ and the $76 \mathrm{bp}$ (Figure 2). More specifically, the rural goats manifested two polymorphic types in the exons 2 and 3 of GH gene, with $75 \%$ showing the same polymorphic types with typical restriction pattern of banded fragments $(435,415$, and $206 \mathrm{bp}$ ) versus $25 \%$ showing a second polymorphic type, with one banded fragment at 206 bp position (figure 1). The reference Saanen buck represented in lane 6 showed a different polymorphic type, with two banded restriction fragments set at 415 and $206 \mathrm{bp}$. On the other hand, the restriction pattern from the digestion of exon 4 of GH resulted in one polymorphic type of two bands, present at 115 and $76 \mathrm{bp}$ (Figure 2), while the reference Saanen buck in lane 6 showed a different polymorphic type with one restriction band, positioned at $76 \mathrm{bp}$.

\begin{tabular}{|c|c|c|c|c|}
\hline \multirow[b]{2}{*}{ Gene ${ }^{(a)}$} & \multicolumn{2}{|l|}{ Primers } & \multirow[b]{2}{*}{ Thermal conditions } & \multirow[b]{2}{*}{ (No. of cycles) } \\
\hline & Sequence & 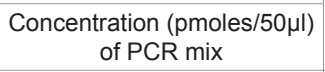 & & \\
\hline $\mathrm{GH}$ & $\begin{array}{l}\text { GH1F: CTCTGCCTGCCCTGGACT } \\
\text { GH1R:GGAGGAGCAGAAGGCAACC } \\
\text { TCAGCAGAGTCTTCACCAAC } \\
\text { CAACAACGCCATCCTCAC }\end{array}$ & 20 & $\begin{array}{l}94^{\circ} \mathrm{C} / 15 \mathrm{~min}, 95^{\circ} \mathrm{C} / 30 \mathrm{~s}, 59^{\circ} \mathrm{C} / 30 \mathrm{~s}, 72^{\circ} \mathrm{C} / 45 \mathrm{~s}, \\
72^{\circ} \mathrm{C} / 7 \mathrm{~min}\end{array}$ & 35 \\
\hline $\begin{array}{l}\text { Casein } \\
\text { CSN1S1 }\end{array}$ & $\begin{array}{l}\text { S1F: 5'TTCTAAAAGTCTCAGAGGCAG3' } \\
\text { S1R 5'GGGTTGATAGCCTTGTATGT3' }\end{array}$ & 50 & $\begin{array}{l}97^{\circ} \mathrm{C} / 2 \mathrm{~min}, 60^{\circ} \mathrm{C} / 45 \mathrm{~s}, 72^{\circ} \mathrm{C} / 2.5 \mathrm{~min}, 94^{\circ} \mathrm{C} / 45 \mathrm{~s} \\
60^{\circ} \mathrm{C} / 45 \mathrm{~s}, 72^{\circ} \mathrm{C} / 2.5 \mathrm{~min}, 72^{\circ} \mathrm{C} / 10 \mathrm{~min}\end{array}$ & 30 \\
\hline MHC Class II DRB & $\begin{array}{l}\text { DRB 1: TATCCCGTCTCTGCAGCACATTTC } \\
\text { DRB2: TCGCCGCTGCACACTGAAACTCTC }\end{array}$ & 20 & $94^{\circ} \mathrm{C} / 1 \mathrm{~min}, 60^{\circ} \mathrm{C} / 1.5 \mathrm{~min}, 72^{\circ} \mathrm{C} / 2 \mathrm{~min}$ & 30 \\
\hline PrP & $\begin{array}{l}\text { PrP G1: 5'ATGGTGAAAAGCCACATAGGCAGT3' } \\
\text { PrP G2: 5'CTATCCTACTATGAGAAAAATGAG3' }\end{array}$ & 20 & $\begin{array}{l}95^{\circ} \mathrm{C} / 5 \mathrm{~min}, 96^{\circ} \mathrm{C} / 2 \mathrm{~min}, 60^{\circ} \mathrm{C} / 2 \mathrm{~min}, 72^{\circ} \mathrm{C} / 3 \mathrm{~min}, \\
72^{\circ} \mathrm{C} / 7 \mathrm{~min}\end{array}$ & 40 \\
\hline
\end{tabular}

(a)DNA level used in all protocols was constant (93.0 $\mathrm{ng} / 50 \mu \mathrm{l}$ reaction mix)

Table 1: Optimized protocol for amplification of multiple genes in DNA of a reference Saanen goat sperms. 
Citation: Barbour EK, Saade MF, Hamadeh SK, Shaib HA, Kassaifi Z, et al. (2013) Genetic Selection Barriers in Global Development of Rural Goat Production and a Simplified Approach in Identification of Proper Polymorphic Types. J Veterinar Sci Technol S11: 004. doi:10.4172/21577579.S11-004

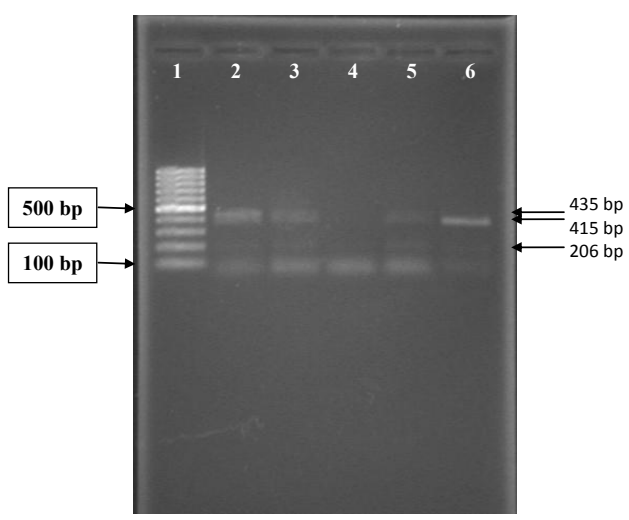

Figure 1: Polymorphism in DNA electrophoretic pattern following Haell endonuclease digestion of PCR-amplified exons 2 and 3 of the Growth Hormone $(\mathrm{GH})$ gene of rural and reference Saanen goat sperms.

Lane 1: 100 bp molecular marker

Lanes 2-5: Haell digested amplicons pattern of 4 respective rural goat's exons 2 and 3 of $\mathrm{GH}$ gene

Lane 6: Haelll digested amplicon of reference Saanen goat's exons 2 and 3 of $\mathrm{GH}$ gene



Figure 2: Polymorphism in DNA electrophoretic pattern following Haell endonuclease digestion of PCR-amplified exon 4 of the Growth Hormone $(\mathrm{GH})$ gene of rural and reference Saanen goat sperms

Lane 1: 100 bp molecular marker

Lanes 2-5: Haelll digested amplicons pattern of 4 respective rural goats' exon 4 of $\mathrm{GH}$ gene

Lane 6: Haelll digested amplicon of reference Saanen goat's exon 4 of $\mathrm{GH}$ gene.

\section{Polymorphism in aS1-Casein Gene}

The digestion of the aS1-Casein gene in sperms of individual rural goats by the XmnI enzyme resulted in four polymorphic types showing the following four restricted bands patterns (Figure 3): undigested $217 \mathrm{bp} ; 50$ and $180 \mathrm{bp} ; 50$ and $167 \mathrm{bp} ; 50,167$ and $217 \mathrm{bp}$. The aS1Casein gene of the reference Saanen goat (lane 6) showed a similar polymorphic type to one of the rural goats, resulting in two restricted bands set at 50 and $180 \mathrm{bp}$.

\section{Polymorphism in MHC Class II DBR gene}

The polymorphism in MHC Class II DRB gene in sperms of rural and reference Saanen goats is deduced from restriction by two enzymes, the PstI and the TaqI (Figure 4). The digestion of MHC Class II DRB gene in all rural and Saanen goats' sperms by PstI endonuclease enzyme resulted in one band at 285, preventing the uncovering of polymorphism (lanes 3-7); however, the digestion of the same gene by the TaqI showed two polymorphic types: a homozygous genotype resulting in an undigested 285 bp band (lanes 8 and 10 for rural goats, and lane 12 for the reference Saanen goat), and a heterozygous genotype resulting in two fragments banded at 150 and 285 bp (lanes 9 and 11 for rural goats).

\section{Polymorphism in Prion (PrP) gene}

The polymorphism in the amino acid sequence at defined positions in the PrP protein-coding exon of rural goat, in reference to Saanen goat sperms, is presented in Table 2. Based on the amino acid sequence between positions 101-194 and 201-240, four PrP haplotypes are detected. No polymorphism was detected at codons positioned at $142,143,146$, or 168 that are associated with phenotypic expression of Transmissible Spongiform Encephalopathy (TSE). In sperms of the third rural goat (L3), there was a replacement of arginine by histidine at position 154, and of serine by proline at codon position of 240 . The relationship of such replacements to susceptibility to TSE will be

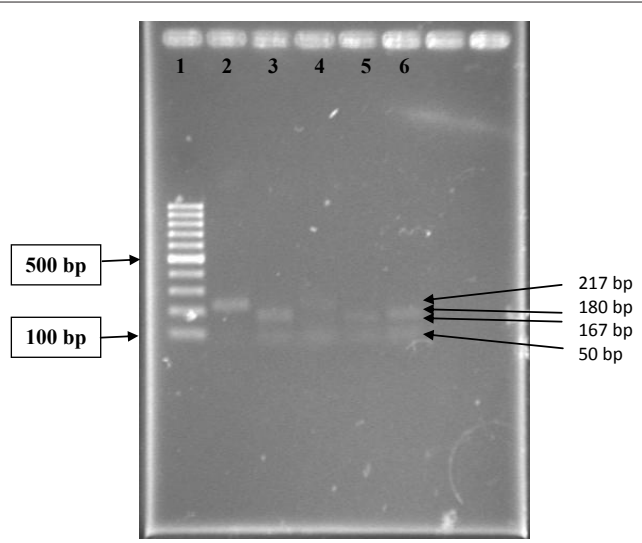

Figure 3: Polymorphism in DNA electrophoretic pattern following $X m n$ endonuclease digestion of PCR-amplified part of the $8^{\text {th }}$ intron, $9^{\text {th }}$ exon, and part of $9^{\text {th }}$ intron of the aS1-Casein gene of rural and reference Saanen goat sperms

Lane 1: 100 bp molecular marker

Lanes 2-5: Xmnl digested amplicons pattern of 4 respective rural goats' aS1Casein gene

Lane 6: Xmnl digested amplicon of reference Saanen goat's aS1-Casein gene

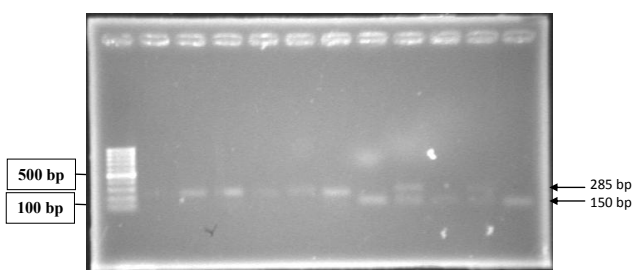

Figure 4: Polymorphism in DNA electrophoretic pattern following Pstl and Taql endonuclease digestion of PCR-amplified MHC class II gene of rural and reference Saanen goat sperms

Lane 1: 100 bp molecular marker

Lane 2: negative control

Lanes 3-6: Pstl digested amplicons pattern of 4 respective rural goats' MHC class II gene

Lane 7: Pstl digested amplicon of reference Saanen goat MHC class II gene Lanes 8-11: Taql digested amplicons pattern of 4 respective rural goats' MHC class II gene

Lane 12: Taql digested amplicon of reference Saanen goat's MHC class II gene. 
Citation: Barbour EK, Saade MF, Hamadeh SK, Shaib HA, Kassaifi Z, et al. (2013) Genetic Selection Barriers in Global Development of Rural Goat Production and a Simplified Approach in Identification of Proper Polymorphic Types. J Veterinar Sci Technol S11: 004. doi:10.4172/21577579.S11-004

Page 4 of 7

\begin{tabular}{|c|c|c|c|c|c|c|c|c|c|c|c|c|c|c|c|c|c|c|}
\hline \multirow{2}{*}{ Individual Bucks ${ }^{(a)}$} & \multicolumn{18}{|c|}{ Sequence of the prion amino acids $^{(b)}$ at positions $101-194$} \\
\hline & 101 & 102 & 107 & 110 & 125 & 127 & 133 & 136 & 137 & 138 & 142 & 143 & 146 & 151 & 154 & 168 & 171 & 194 \\
\hline L1 & Q & W & $\mathrm{S}$ & $\mathrm{T}$ & V & G & L & A & M & $\mathrm{S}$ & I & $\mathrm{H}$ & $\mathrm{N}$ & $\mathrm{R}$ & $\mathrm{R}$ & $P$ & $Q$ & $\mathrm{~T}$ \\
\hline L2 & $Q$ & W & $\mathrm{K}$ & $\mathrm{T}$ & V & $\mathrm{G}$ & $L$ & A & $\mathrm{M}$ & $S$ & I & $\mathrm{H}$ & $\mathrm{N}$ & $\mathrm{R}$ & $\mathrm{R}$ & $P$ & $Q$ & $\mathrm{~T}$ \\
\hline L3 & $S$ & $G$ & $S$ & $\mathrm{~T}$ & $\mathrm{~V}$ & $\mathrm{G}$ & $\mathrm{L}$ & A & $M$ & $S$ & I & $\mathrm{H}$ & $\mathrm{N}$ & $X$ & $\mathrm{H}$ & $P$ & $\mathrm{R}$ & $\mathrm{T}$ \\
\hline S1 & $x$ & $x$ & $x$ & $x$ & $x$ & $x$ & $X$ & $A$ & $M$ & $x$ & I & $\mathrm{H}$ & $\mathrm{N}$ & $P$ & $\mathrm{R}$ & $\mathrm{P}$ & $Q$ & $\mathrm{~T}$ \\
\hline
\end{tabular}

\begin{tabular}{|c|c|c|c|c|c|c|c|c|c|}
\hline \multirow{2}{*}{ Individual Bucks ${ }^{(a)}$} & \multicolumn{9}{|c|}{ Sequence of the prion amino acids $^{(b)}$ at positions $201-240$} \\
\hline & 201 & 202 & 207 & 211 & 218 & 219 & 220 & 222 & 240 \\
\hline L1 & $\mathrm{F}$ & $\mathrm{T}$ & $\mathrm{K}$ & $\mathrm{R}$ & I & $\mathrm{T}$ & Q & $\mathrm{P}$ & $\mathrm{S}$ \\
\hline L2 & $\mathrm{F}$ & $\mathrm{T}$ & $\mathrm{K}$ & $\mathrm{R}$ & I & $x$ & Q & L & $x$ \\
\hline L3 & $\mathrm{F}$ & $T$ & $\mathrm{~K}$ & $\mathrm{R}$ & I & $X$ & $Q$ & $\mathrm{P}$ & $P$ \\
\hline $\mathrm{S} 1$ & $x$ & $P$ & $\mathrm{R}$ & $E$ & 1 & $\mathrm{~T}$ & $x$ & $E$ & $\mathrm{~S}$ \\
\hline
\end{tabular}

(a) $L=$ Lebanese local bucks, $S=$ Saanen buck

(b) $\mathrm{A}=$ Alanine, $\mathrm{E}=$ Glutamic acid, $\mathrm{F}=$ Phenylalanine, $\mathrm{G}=$ Glycine, $\mathrm{H}=$ Histidine, $\mathrm{I}=$ Isoleucine, $\mathrm{K}=$ Lysine, $\mathrm{L}=\mathrm{Le}$ cine, $\mathrm{M}=\mathrm{Methionine}, \mathrm{N}=\mathrm{Asparagine}, \mathrm{P}=\mathrm{Proline}, \mathrm{Q}=\mathrm{Glutamine}$, $\mathrm{R}=$ Arginine, $\mathrm{S}=$ Serine, $\mathrm{T}=$ Threonine, $\mathrm{V}=$ Valine, $\mathrm{W}=$ Tryptophan, $\mathrm{X}=$ Unknown Amino-Aci

Table 2: Polymorphism in amino-acid sequences at defined positions in prion (PrP) protein coding exon of rural goat (L1, L2, and L3) sperms, using Saanen (S1) sperm DNA as a reference.

discussed. Moreover, there was a similar polymorphism shown in all rural goats at amino acid position 136 (alanine), 154 (arginine) and 171 (glutamine); such positions are also critical in judgment of susceptibility or resistance to TSE.

\section{Discussion}

\section{Polymorphism in Growth Hormone (GH)}

The HaeIII endonuclease used in digestion of the GH gene amplicons (Figures 1 and 2) of rural and reference Saanen sperms had a $5^{`}$ GG/CC3' restriction site [25]. According to previously reported restriction banding patterns produced by HaeIII applicability on GH gene of goats $[18,26]$, the obtained pattern by the sperms of all rural goats belongs to the reported $\mathrm{CD}$ genotype, while that obtained by the Saanen belongs to the reported CC genotype. It is worth noting that the CC genotype resulted in better growth traits and performance, and significantly higher prolificacy and superovulation response in goats $[18,26]$; actually, a five times higher performance in production of milk is reported in Saanen compared to these rural goats, a data that is documented in our previous work [27]. It is advised to combine the polymorphism in exon 2 and 3 to that of exon 4 of GH gene, to get a more profound genetic-model for future selection. Actually, Hua et al. [18] in 2009 recommended excluding the Boer with a genotype AACD for GH gene, since it was associated with poor growth performance. In addition, Zhang et al. [26] reported that both the Matou and Boer dams with $\mathrm{ABCD}$ genotype for $\mathrm{GH}$ gene had the largest litter size, while those with AACD genotype were associated with the lowest litter size, a marker in the genotype that should be included in future selection models for better performance. The search for CC and/or ABCD genotype for GH gene in rural goats should be continued to include in future model for rural goat selection.

\section{Polymorphism in aS1-Casein gene}

The restriction site of $\mathrm{Xm} n \mathrm{I}$ endonuclease used in digestion of the sperms-aS1-Casein gene is 5 'GAANN/NNTTC3' [28]. The digestion resulted in four different banding patterns of the sperm's aS1-Casein gene fragments of four respective individual bucks (Figure 3). According to Ramunno et al. [28], the XmnI endonuclease digestion banding patterns of the goat $\alpha \mathrm{S} 1$-Casein gene were correlated with a cytosine presence or absence at 23 nucleotide of the $9^{\text {th }}$ exon of the goat aS1Casein gene. The deletion of the cytosine at the indicated position (D+) is confirmed whenever the $\mathrm{X} m n \mathrm{I}$ endonuclease digestion fails, while a success in digestion is indicative of the absence of such a deletion (D-). The failure in digestion of $\alpha$ S1-Casein gene in one rural goat, with one band set at $217 \mathrm{bp}$ (Figure 3, lane 2), is indicative of a deletion on both alleles $(\mathrm{D}+/ \mathrm{D}+)$, while the success of digestion in the aS1-Casein gene of an individual rural goat, represented in Figure 3, lane 4, resulting in 50,167, and $217 \mathrm{bp}$ fragments indicates a cytosine deletion in one allele (D+/D-). The other two rural goats in figure 3, lanes 3 and 5 , and the reference Saanen goat in lane 6 had no deletions of cytosine. The obtained digestion fragments-patterns of aS1-Casein gene allow to assign a genotype to each rural and reference Saanen goat included in this study $[28,29]$. Thus, rural goats in Figure 3 lanes 2-5, conform to respective genotypes $c / c, b / b, a / c$, and $a / a$, while the reference Saanen agrees with the $\mathrm{b} / \mathrm{b}$ genotype. The ' $\mathrm{d}$ ' genotype genotype was absent in the goats included in this research. Da Silva et al. [30] reported the absence of the 'a' genotype in Mexican goats, whereas all genotypes (ad) were present in Egyptian, Italian, and Indian goats [28,29,31].

It is worth noting that some amplicons of the aS1-Casein gene had an eleven bp insertion (I+), while other didn't (I-). The respective size of amplicons for aS1-Casein of rural goats present in Figure 3, lanes 2- 5 were 217(I-), 230 (I+), 217(I-), and that for reference Saanen was $230 \mathrm{bp}(\mathrm{I}+)$ [23].This 11 nucleotide insertion is characterized before as CGTAATGTTTC, located at 73 nucleotides downstream of 5 ' splice site of the $9^{\text {th }}$ intron of the aS1-Casein [28]. The assignment of alleles to the goat $\mathrm{\alpha S} 1$-Casein is linked in literature to D (presence or absence of cytosine deletion at $23^{\text {rd }}$ nucleotide of the $9^{\text {th }}$ exon) and I (presence or absence of the 11 nucleotide insertion) [28].

Accordingly, the rural goats presented in lanes 2, 3, 4, and 5 (Figure 3), and having respective $\mathrm{D}$ and I as D+I-, D-I+, D-I-/D+I-, D-I-, will be assigned the following respective aS1-Casein alleles: $\mathrm{D}, \mathrm{B}$ or $\mathrm{E}, \mathrm{A}$ or $\mathrm{O} 1 / \mathrm{D}$, and $\mathrm{A}$ or $\mathrm{O} 1$. It is worth noting that the 'A' allele is proven to be associated with high level of aS1-Casein in milk while the 'B' and ' $E$ ' allele are associated with high and medium levels of aS1-Casein in milk, respectively [28]. Moreover, the ' $D$ ' allele is associated with medium levels of aS1-Casein in milk [29,31], which could be selected in future programs to produce milk with lower aS1-Casein level, targeting allergic consumers, and developments of special infant diets [29]. The high polymorphism in the aS1-Casein gene is helpful to use as genetic markers in the future model for selection of goats with high or low Casein protein levels in milk, depending on the demand of the targeted consumers. 
Citation: Barbour EK, Saade MF, Hamadeh SK, Shaib HA, Kassaifi Z, et al. (2013) Genetic Selection Barriers in Global Development of Rural Goat Production and a Simplified Approach in Identification of Proper Polymorphic Types. J Veterinar Sci Technol S11: 004. doi:10.4172/21577579.S11-004

Page 5 of 7

\section{Polymorphism in MHC Class II DRB Gene}

The polymorphism in MHC Class II DRB gene in sperms of rural and reference Saanen goats, created from the restriction by PstI and the TaqI is documented in Figure 4. The respective restriction sites of Pst $\mathrm{I}$

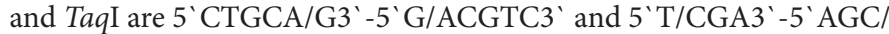
T3', as confirmed by Amills et al. [32].

The uniform result of one band of $285 \mathrm{bp}$ size, by the digestion of MHC Class II DRB amplicons by PstI of all rural and reference Saanen goat-sperms, reveals the absence of a CTGCAG or GACGTC nucleotide sequence in exon 2 of this gene in all included goats (Figure 4, lanes 3-7). The absence of PstI restriction site reflects the presence of a GTG (valine) or TGT (cytosine) codons at position 78 of exon 2 [32,33]. The Spanish caprine breeds showed two restriction patterns, following a digestion by the PstI restriction enzyme, namely two fragments of 15 and $270 \mathrm{bp}$, and three fragments pattern of 15, 44, and a $226 \mathrm{bp}$ [5]. However, the PstI restriction of the MHC Class II DRB gene of Egyptian goat genome resulted in respective homozygosity and heterozygosity equivalent to 29.5 and $70.5 \%$ [33].

The electrophoretic pattern of TaqI digested amplicons of the MHC Class II DRB showed two restriction patterns, a one undigested $285 \mathrm{bp}$ band (Figure 4, lanes 8 and 10 for rural goats, and lane 12 for reference Saanen goat), and a two bands pattern at 150 and 285 bp (Figure 4, lanes 9 and 11 for rural goats). The presence of one-band pattern is indicative of a homozygous genotype in two out of the four rural goats, and in the reference Saanen goat; on the other hand, the presence of a two bands-pattern confirms the presence of a heterozygous genotype in the other two rural goats. It is worth noting that Ahmed and Othman [33] documented in Egyptian goat genome the presence of a homozygous tt genotype (9.1\%) in MHC Class II DRB gene resulting in one bandpattern (285 bp), a homozygous TT genotype (29.5\%) with two bandspattern (122 and $163 \mathrm{bp}$ ), and a heterozygous Tt genotype that had a three bands-pattern at 122, 163, and 385 bp. Moreover, the MHC Class II DRB gene of Spanish goats subjected to TaqI restriction had the following respective percentages of $\mathrm{Tt}$ and $\mathrm{tt}$ genotypes in MHC Class II DRB gene namely, 65 and 35\%.

The relationship of such polymorphism in the MHC Class II DRB gene to humoral and cell-mediated immunity to economic diseases of goats will be the subject of the future investigation, to allow for selections of highly immune individuals.

\section{Polymorphism in Prion (PrP) gene}

The polymorphism in sequences of the PrP gene in rural and reference Saanen goat-sperms, between amino acid positions of 101194 and 201-240, having specific codons affecting the susceptibility in goats to Transmissible Spongiform Encephalopathy (TSE), is presented in Table 2. Four PrP haplotypes were found based on the detected amino acid sequences. Amino acids dimorphisms were observed in codons 101, 102, 107, 151, 154, 171, 202, 207, 211, and 240, and three different mutations at codon 222. The following three polymorphisms in $\mathrm{PrP}$ amplicons were not reported previously for the following codons: codon 101, glutamine was substituted by serine; codon 107, lysine was substituted by serine; codon 222 , glutamine was substituted by proline or leucine.

These aforementioned polymorphisms were found in $\mathrm{PrP}$ amplicons of rural goats, while the remaining five polymorphisms were present all together in one haplotype of the reference Saanen goat, mainly at codon 151, in which arginine was substituted by proline, at codon 202, in which proline replaced theronine, at codon 207 , where lysine was substituted by arginine, at codon 211 , in which arginine was substituted by glutamic acid, while at codon 222 , the glutamic acid was replaced by glutamine.

The dimorphisms in codons of PrP amplicons, reported previously in goats, were present at codon $102(\mathrm{~W} \rightarrow \mathrm{G})$, codon $154(\mathrm{R} \rightarrow \mathrm{Il})$ [34], codon $171(\mathrm{Q} \rightarrow \mathrm{R})$ [35], and finally at codon $240(\mathrm{~S} \rightarrow \mathrm{P})[36,37]$.

No polymorphisms were found at codons 142, 143, 146, 168 that are associated with differences in phenotypic expression of TSE in goats [35]. In fact a substitution of isoleucine by methionine at codon 142 has altered the TSE-incubation period in goats [34,38]; in addition, a substitution of asparagine by serine or aspartic acid at codon 146 has been associated with resistance to TSE [35]. However, the simultaneous presence of isoleucine at codon 142 and asparagine at codon 146, as obtained in our study (Table 2), were found to be associated with an atypical TSE in Swiss goats [39]. In addition, the replacement of arginine by histidine in one rural goat at codon 154 (Table 2) has a variable protective effect against TSE, depending on the goat breed $[40,41]$; actually this mutation $(\mathrm{R} \rightarrow \mathrm{H})$ provided some TSE-protection in Dman and Chaouni goats [42] leading to less frequency in TSE of goats [43]; on the contrary, this substitution $(\mathrm{R} \rightarrow \mathrm{H})$ at codon 154 created a risk factor of atypical TSE in goats [44]

The dimorphism shown in codon 240 (serine $\rightarrow$ proline) is not reported in other ruminants [34], and its presence is documented in PrP gene of mink, ferret, domestic dog, and dingo $[45,46]$. The role of substitution of serine by proline at codon 240 , in relation to TSE susceptibility, is controversial. Bouzalas et al. [35] reported that such a substitution creates a partial protection from clinical TSE, without an increase in resistance to prion infection in goats. The dual presence of proline in codon 240 and histidine at position 154, as documented for rural goat L3 in Table 2 is reported to confer a partial resistance to TSE [34,47], while others [40] claimed a positive correlation between presence of proline at codon 240 with TSE manifestation. Several studies showed no association between the codon 240 polymorphism in $\operatorname{PrP}$ and the occurrence of TSE $[34,38,43,47,48]$.

The presence of a similar PrP-amino acid sequence at codons 136 (alanine), 154 (arginine), and 171 (glutamine) in each of three rural goats and in the reference Saanen goat (Table 2) indicates a similarity to scrapie susceptibility in sheep [49]. Fortunately, one rural goat (L3 in Table 2) showed a novel haplotype of alanine (codon 136), histidine (codon 154), and arginine (codon 171). It is important to study in the future the correlation of such novel patterns of amino acid sequences in PrP gene to susceptibilities to TSE in goats, to help in selection for resistance to this economic zoonotic disease.

In conclusion, the search for $\mathrm{CC}$ and/or $\mathrm{ABCD}$ genotype for $\mathrm{GH}$ gene in rural goats is needed to be used in the future selection model for production improvements. The polymorphism in the aS1-Casein gene detected in this research is helpful in selection of goats for high or low casein protein level in the produced milk. The TaqI endonuclease succeeded in resulting with a polymorphism in MHC class II DRB gene, while PstI failed; the relationship of polymorphism created by the TaqI enzymes to selection for improvement of humoral and cellmediated immunity will be the subject of future investigation. The relationship of the novel polymorphism present in the specific amino acid sequences of the PrP gene of the rural goats to susceptibility to TSE needs to be investigated to allow for future selection programs to result in goats that are resistant to this economic disease and that provide safe foods to human consumers. The presence of multiple polymorphism in the studied 4 genes allow for assigning genetic markers in selection 
Citation: Barbour EK, Saade MF, Hamadeh SK, Shaib HA, Kassaifi Z, et al. (2013) Genetic Selection Barriers in Global Development of Rural Goat Production and a Simplified Approach in Identification of Proper Polymorphic Types. J Veterinar Sci Technol S11: 004. doi:10.4172/21577579.S11-004

Page 6 of 7

programs that target inclusive improvements, not only in production, but in immunity, and resistance to zoonotic TSE in rural goats.

\section{References}

1. http://data.worldbank.org/indicator/SP.RUR.TOTL

2. Devendra C (2010) Concluding synthesis and the future for sustainable goat production. Small Rumin Res 89: 125-130.

3. Khan BB, Arshad I, Mustafa MI (2003) Sheep and goat production. Department of Livestock Management, University of Agriculture, Faisalabad, Pakistan.

4. Ahuya CO, Okeyo AM, Mwangi-Njuru, Peacock CM (2005) Developmental challenges and opportunities in the goat industry: The Kenyan experience. Small Rumin Res 60: 197-206.

5. Kumar S, Vaid RK, Sagar RL (2006) Contribution of goats to livelihood security of small ruminant farmers in semiarid region. IJSR 12: 61-66.

6. Gizaw S, Tegegne A, Gebremedhin B, Hoekstra D (2010) Sheep and goat production and marketing systems in Ethiopia: characteristics and strategies for improvement. IPMS (Improving Productivity and Market Success) of Ethiopian Farmers. Nairobi. International Livestock Research Institute, Kenya.

7. Kumar S, Vihan VS, Deoghare PR (2003) Economic implication of diseases in goats in India with reference to implementation of a health plan calendar. Small Ruminant Res 47: 159-164.

8. Rumosa Gwaze F, Chimonyo M, Dzama K (2009) Communal goat production in Southern Africa: a review. Trop Anim Health Prod 41: 1157-1168.

9. Dubeuf JP (2011) The social and environmental challenges faced by goat and small livestock local activities: Present contribution of research-development and stakes for the future. Small Rumin Res 98: 3-8.

10. Fontanesi L, Martelli PL, Beretti F, Riggio V, Dall'Olio S, et al. (2010) An initial comparative map of copy number variations in the goat (Capra hircus) genome. BMC Genomics 11: 639.

11. Iniguez L (2004) Goats in resource-poor systems in the dry environments of West Asia, Central Asia and the Inter-Andean valleys. Small Rumin Res 51: 137-144.

12. Gama LT, Bressan MC (2011) Biotechnology applications for the sustainable management of goat genetic resources. Small Rumin Res 98: 133-146.

13. De Araújo AM, Guimarães SEF, Machado TMM, Lopes PS, Pereira CS, et al (2006) Genetic diversity between herds of Alpine and Saanen dairy goats and the naturalized Brazilian moxotó breed. Gen Mol Biol 29: 67-74.

14. Bélichon S, Manfredi E, Piacère A (1998) Genetic parameters of dairy traits in the Alpine and Saanen goat breeds. Genet Sel Evol 30: 529-534.

15. Iñiguez $L$ (2005) Characterization of small ruminant genetic resources in Central Asia, the Caucasus, West Asia and North Africa. International Center for Agricultural Research in the Dry Areas (ICARDA), Aleppo, Syria Arab Republic.

16. Mavrogenis AP, Antoniades NY, Hooper RW (2006) The Damascus (Shami) goat of Cyprus. AGRI 38: 57-65.

17. Dubeuf JP, Boyazoglu J (2009) An international panorama of goat selection and breeds. Livestock Sci 120: 225-231.

18. Hua GH, Chen SL, Yu JN, Cai KL, Wu CJ, et al. (2009) Polymorphism of the Growth Hormone gene and its association with growth traits in Boer goat bucks. Meat Sci 81: 391-395.

19. Pagano RI, Pennisi P, Valenti B, Lanza M, Di Trana A, et al. (2010) Effect of CSN1S1 genotype and its interaction with diet energy level on milk production and quality in Girgentana goats fed ad libitum. J Dairy Res 77: 245-251.

20. Mainguy J, Worley K, Côté SD, Coltman DW (2007) Low MHC DRB Class I diversity in the mountain goat: past bottlenecks and possible role of pathogens and parasites. Conserv Gen 8: 885-891.

21. Collinge $J(2010)$ Medicine. Prion strain mutation and selection. Science 328 $1111-1112$

22. 22. Papasavva-Stylianou $P$, Kleanthous $M$, Toumazos $P$, Mavrikiou $P$, Loucaides P. (2007) Novel polymorphisms at codons 146 and 151 in the prion protein gene of Cyprus goats, and their association with natural scrapie. Vet J 173: 459-462.

23. Barbour EK, Saadé MF, Sleiman FT, Hamadeh SK, Mouneimne Y, et al. (2012) Optimization of Saanen sperm genes amplification: evaluation of standardized protocols in genetically uncharacterized rural goats reared under a subtropical environment. Trop Anim Health Prod 44: 1513-1519.

24. Saadé MF (2011) Optimization of sperm sexing and gene characterization in goats. American University of Beirut 1-134.

25. Goeddel DV, Heyneker HL (1986) Microbial expression of a gene for human growth hormone. US Patent 4: 601-980.

26. Zhang C, Liu Y, Huang K, Zeng W, Xu D, et al. (2010) The association of two single nucleotide polymorphisms (SNPs) in growth hormone (GH) gene with litter size and superovulation response in goat-breeds. Gen Mol Biol 34: 49-55.

27. Barbour EK, Itani HH, Sleiman FT, Saade MF, Harakeh S, et al. (2012) Preliminary comparison of different immune and production components in local and imported Saanen goats reared under a sub-tropical environment. Trop Anim Health Prod 44: 87-93.

28. Ramunno L, Cosenza G, Pappalardo M, Pastore N, Gallo D, et al. (2000) Identification of the goat CSN1S1F allele by means of PCR-RFLP method. Anim Genet 31: 342-343.

29. Ahmed S (2006) Identification of Egyptian goat aS1-Casein alleles using PCRRFLP method. Inter J Dairy Sci 1: 27-31.

30. Da Silva AA, Adrião M, Jimenez GC, Da Rocha Santos MC, Wischral A, et al. (2007) Study of the genetic polymorphism of the aS1-Casein in goats of Pernambuco state, Brazil. Acta Scient Animal Sci 29: 255-259.

31. Kumar A, Rout PK, Mandal A, Roy R (2007) Identification of the CSN1S1 allele in Indian goats by the PCR-RFLP method. Animal 1: 1099-1104.

32. Amills M, Francino O, SanchezA (1995) Nested PCR allows the characterization of Taql and Pstl RFLPs in the second exon of the caprine MHC class II DRB gene. Vet Immunol Immunopathol 48: 313-321.

33. Ahmed S, Othman OE (2006) A PCR-RFLP method of the analysis of Egyptian goat MHC Class II DRB Gene. Biotech 5: 58-61.

34. Billinis C, Panagiotidis CH, Psychas V, Argyroudis S, Nicolaou A, et al. (2002) Prion protein gene polymorphisms in natural goat scrapie. J Gen Virol 83: 713 721

35. Bouzalas IG, Dovas Cl, Banos G, Papanastasopoulou M, Kritas S, et al. (2010) Caprine PRNP polymorphisms at codons 171, 211, 222 and 240 in a Greek herd and their association with classical scrapie. J Gen Virol 91: 1629-1634.

36. Vaccari G, Panagiotidis CH, Acin C, Peletto S, Barillet F, et al. (2009) State-ofthe-art review of goat TSE in the European Union, with special emphasis on PRNP genetics and epidemiology. Vet Res 40: 48

37. Van Poucke M, Willemarck N, Hugot K, Van Zeveren A, Peelman LJ (2009) Complete genomic sequence of the goat prion protein gene (PRNP). Virus Genes 38: 189-192.

38. Goldmann W, Martin T, Foster J, Hughes S, Smith G, et al. (1996) Novel polymorphisms in the caprine PrP gene: a codon 142 mutation associated with scrapie incubation period. J Gen Virol 77: 2885-2891.

39. Seuberlich T, Botteron C, Benestad SL, Brunisholz H, Wyss R, et al. (2007) Atypical scrapie in a Swiss goat and implications for transmissible spongiform encephalopathy surveillance. J Vet Diag Invest 19: 2-8

40. Acutis PL, Sbaiz L, Verburg F, Riina MV, Ru G, et al. (2004) Low frequency of the scrapie resistance-associated allele and presence of lysine-171 allele of the prion protein gene in Italian Biellese ovine breed. J Gen Virol 85: 3165-3172.

41. Vascellari M, Aufiero GM, Nonno R, Agrimi U, Vaccari G, et al. (2005) Diagnosis and PrP genotype target of scrapie in clinically healthy sheep of Massese breed in the framework of a scrapie eradication programme. Arch Virol 150: 19591976.

42. Serrano C, Hammouchi M, Benomar A, Lyahyai J, Ranera B, et al. (2009) PRNP haplotype distribution in Moroccan goats. Anim Genet 40: 565-568.

43. Barillet $F$, Mariat $D$, Amigues $Y$, Faugeras $R$, Caillat $H$, et al. (2009) Identification of seven haplotypes of the caprine PrP gene at codons 127, 142, 154, 211 222 and 240 in French Alpine and Saanen breeds and their association with classical scrapie. J Gen Virol 90: 769-776.

44. Colussi S, Vaccari G, Maurella C, Bona C, Lorenzetti R, et al. (2008) Histidine at codon 154 of the prion protein gene is a risk factor for Nor98 scrapie in goats. J Gen Virol 89: 3173-3176.

45. Bartz JC, Mckenzie DI, Bessen RA, Marsh RF, Aiken JM (1994) Transmissible 
Citation: Barbour EK, Saade MF, Hamadeh SK, Shaib HA, Kassaifi Z, et al. (2013) Genetic Selection Barriers in Global Development of Rural Goat Production and a Simplified Approach in Identification of Proper Polymorphic Types. J Veterinar Sci Technol S11: 004. doi:10.4172/21577579.S11-004

mink encephalopathy species barrier effect between ferret and mink: PrP gene and protein analysis. J Gen Virol 75: 2947-2953.

46. Wopfner F, Weidenhöfer G, Schneider R, von Brunn A, Gilch S, et al. (1999) Analysis of 27 mammalian and 9 avian PrPs reveals high conservation of flexible regions of the prion protein. J Mol Biol 289: 1163-1178.

47. Mariat $D$, Andreoletti $O$, Perrin-Chauvineau $C$, Corbière $F$, Piacère $A$, et al. (2006) Identification of PrP gene polymorphisms in Alpine and Saanen French goats associated with susceptibility to scrapie. Proceed. $8^{\text {th } W o r l d ~ C o n g . ~ G e n ~}$ Appl Livestock Prod, Belo Horizonte, Minas Gerais, Brazil.

48. Vaccari G, Di Bari MA, Morelli L, Nonno R, Chiappini B, et al. (2006) Identification of an allelic variant of the goat $\operatorname{PrP}$ gene associated with resistance to scrapie. J Gen Virol 87: 1395-1402.

49. Sasazaki S, Nagato T, Mannen $H$ (2008) Genetic diversity of prion protein gene in Asian native goat. Small Rum Res80: 101-103. 